\title{
An examination on the feed-in tariff policy for renewable electricity: Taiwan's case example
}

\author{
Chung-Chiang Chen
}

Received: 18 April 2012/Revised: 8 April 2013/Accepted: 23 April 2013/Published online: 26 June 2013

(C) Islamic Azad University (IAU) 2013

\begin{abstract}
Taiwan's feed-in tariff (FIT) policy, revised in 2009 , sets a goal to increase the installation capacity 6,500-10,000 MW (megawatts) of renewable power systems in 20 years. The purpose of this paper is to examine whether the goal can be achieved or not. This paper presents an overview of FIT policies implemented in some leading countries and their performance of renewable electricity installed capacity and generation. This paper presents two outlook scenarios for Taiwan's renewable power installation capacity by using Germany as a benchmark after a detailed analysis and discussion on Taiwan's historical evolution of renewable energies. The Moderate Scenario projects that total cumulative capacity of renewable power systems increases from 5,813.8 MW in 2010 to 7,245.99 MW in 2030, while the Optimistic Scenario estimates the total renewable power capacity will be 11,977.14 MW in 2030. The total increase in the new installation capacity attain to 1,432.19 and 6,163.64 MW for the two scenarios, respectively.
\end{abstract}

Keywords Feed-in tariff (fit) - Wind power - Solar PV . Renewable electricity · Energy policy

\section{Introduction}

Renewable electricity has relatively higher costs in production than conventional fossil-fueled electricity, and thus, it has not yet fully developed in the world. Numerous

C.-C. Chen $(\square)$

Master Program of Leisure Environment Management, Department of Tourism Management, Nanhua University, 55, Nanhua Road, Sect. 1, Dalin, Chiayi 622, Taiwan e-mail: ccchen@mail.nhu.edu.tw promotional and subsidy programs have recently been implemented by many countries in the world for the development of various renewable energies. The feed-in tariff (FIT) policy has been implemented by many countries and proved to perform well to trigger a considerable increase in renewable electricity production. In general, it may be seen as an effective supporting mechanism for the successful development of newly emerging renewable energy technology (Couture and Gagnon 2010; Mendonca 2007; Rowlands 2005, 2007) since it can reduce the financial risks for renewable energy technology developers (Mitchell and Connor 2004) and deploy the installation of renewable energy systems at lower cost than other policy mechanisms (Lipp 2007; Butler and Neuhoff 2008; Fouquet and Johansson 2008).

The FIT policy is basically used to promote renewable energies that aim to reduce emissions of green house gases and air pollutants, together with several competing objectives that attempt to reduce dependence on fossil fuels and to increase portfolio diversity and energy security. Many researchers focus on the assessment of FIT schemes that implemented in some countries for renewable technology (e.g., Rowlands 2005; Astrand and Neij 2006; Jacobsson and Lauber 2006; Butler and Neuhoff 2008; Mitchell et al. 2006; Del Rio and Gual 2007). The FIT level is designed and determined by levelizing the generation costs by the government, so that the renewable power systems can be efficiently for operation and cost effectively for development (Mendonca 2007; Klein 2008). In practice, it varies according to the type of technology, the size of the installed power systems, the location of the project, and a number of other project-specific variables (Mendonca 2007; Fouquet and Johansson 2008; Langniss et al. 2009). The other streamline of literature focuses on the cost effectiveness of FIT policies. Foxon and Pearson (2007) and Finon and 
Perez (2007) present frameworks to evaluate the factor affecting the efficiency of renewable policies. Butler and Neuhoff (2008) compare the FIT schemes for market-based deployment of renewable energy. They find that the feed-in tariff implemented in the UK and Germany may bring about cost reduction for consumers and larger deployment. Many researchers argue that feed-in tariff policies may be the most effective tool at low cost to encourage the development of renewable energy (Lipp 2007; Butler and Neuhoff 2008; Fouquet and Johansson 2008). The analysis result of Sarzynski et al. (2012) also finds that financial incentives like rebates may result in more extensive and rapid deployment of grid-tied PV technology.

In order to improve the market efficiency, Taiwan has started to liberalize the electricity market. In 1999, a coal-fired power plant was installed by Formosa Plastics Corp with total capacity of 1,800 MW. The liberalization campaign asked Taiwan Power Company (TPC, the government's attorney) to purchase electricity from the private-owned power plant (independent power producers, IPPs) at a price that is determined at the levelized cost based on a 25-year power purchase agreements between IPPs. The electricity generated by IPPs should be fed in the grid. Such a system is quite similar to FIT policies that ask the utilities to be obliged to purchase the electricity generated from the renewable resources at a guarantee price for a fixed period of time.

Considering the high impact arising from the generation of conventional energies, Taiwan government has tried to switch its energy policies by rising up the share of renewable energy production since 2000s. In 2003, Taiwan set a goal of $10 \%$ share of renewable electricity in total power generation by 2010. In 2009, the "Directive for promoting renewable energy (DPRE)" was passed and put into effect after a long time of legislative debate, in which the feed-in policy was regulated as a tool to encourage the installation of renewable power systems. Taiwan government argues that the major purpose of the FIT policy is to promote the consumption of renewable energies for the increase in energy security, enhancement of domestic power generation capacity, minimization of power generating costs, and stabilization of fuel stocks costs. Taiwan government expects that the implementation of DPRE can lead to a goal of $50 \%$ of 2000 emission levels by 2050 (BOE 2009) and an increase 6,500-10,000 MW of renewable installation capacity in 20 years. In March 2011, the feed-in tariff rates (the payment for purchasing electricity generated from renewable source) were announced for a variety of renewable power generation.

It is generally accepted that the development and promotion of renewable energies play a key role for the goal of $\mathrm{CO} 2$ mitigation. To analyze the important role of energy policies in affecting the development of renewable energies, many authors present a variety of frameworks (e.g.,
Ackermann et al. 2001; Meyer 2003). Mitchell et al. (2006) employ the framework presented by Foxon et al. (2005) to evaluate the effectiveness of the renewable electricity policies introduced in England and Germany. They argue that risk reduction is an important criterion in evaluating the effectiveness of policies in supporting renewable electricity. Many researchers employ SWOT to identify factors that affect the relative competitiveness involving renewable energy development strategy. For example, Dincer (2011) overviews the photovoltaic technology status and perspective in Turkey, and analyze the SWOT of Turkey's photovoltaic industry. Terrados et al. (2007) focus on a renewable energy development project to diagnose current problems and to sketch future action lines.

This paper attempts to assess the impact of FIT policies on the deployment of renewable energies by using Taiwan as a case example. And thus, the theme of this paper focuses on the outlook of renewable power systems in Taiwan. This paper employs a qualitative method by comparing FIT policies implemented between Taiwan and some leading countries and uses the historical trend of renewable power production to project the future development. This article is organized as follows: Sect. 2 provides an overview of the renewable electricity generation in Taiwan and a qualitative method for the scenario analysis is presented. In Sect. 3.1, we review the renewable electricity generation in some leading countries. In Sect. 3.2, we review the historical evolution of Taiwan's renewable energy policies and analyze the policy performance by comparing the goal designed in earlier days and the data performed. Section 4 introduces the "feed-in tariffs" scheme implemented in Taiwan. Section 3.3 provides two outlook scenarios for Taiwan's installation capacity of renewable power systems. The scenarios attempt to examine whether the goal set in the DPRE can be achieved or not. A brief conclusion is made in Sect. 4 with a summary of lessons learned from the past policy making in Taiwan. This research was carried out from July 2011 to February 2012 at the Department of Tourism Management, Nanhua University, Taiwan.

\section{Materials and methods}

This paper uses Taiwan's development experience as an example to analyze the FIT policy on the deployment of renewable power systems. The data involving the energy production and consumption and the relevant FIT policies are provided by a variety of source including the governmental agency in charge of energy management and administration like BOE (Bureau of Energy, Taiwan), EIA (Energy Information Administration), IEA (International Energy Agency), and the associations in relating to renewable energy production or solar PV systems 
marketing such as EPIA (European Photovoltaic Industry Association), ESTWLA (European Solar Thermal Electricity Association), EWEA (the European Wind Energy Association). This paper also reviews the current status of renewable energy generation in some of the leading countries and compares the feed-in tariffs policies of these leading countries and Taiwan. Furthermore, a forecasting on Taiwan's future development of renewable energy production is conducted based on the historical data.

The renewable energy resource has been seen as the major priority of energy source in Taiwan's relevant policies until now. In 2003, Taiwan set a goal of $10 \%$ share of renewable electricity in total generation by 2010 according to the "Non-nuclear homeland policy." In 2005, Ministry of Economic Affairs (MOEA) set a goal that the renewable power systems should be installed more than 5,130 MW by $2010,7-8,000$ MW by 2020 , and $8-9,000$ MW by 2025 (MOEA 2005). Furthermore, the installed capacity would reach 2,159 MW for wind power and $21 \mathrm{MW}$ for solar PV power systems by 2010 .

In order to promote the installation of various renewable production systems, Taiwan has implemented some promotion programs to encourage the installation of renewable power systems by providing financial subsidy. As of 2000, a support program was announced by Taiwan MOEA for wind power demonstration projects with subsidies up to $50 \%$ of the installation costs for wind power demonstration systems. In 2005, a formal support mechanism in Taiwan was implemented for the installation of renewable power systems including wind turbines and solar PV power system. The subsidy rate depends on the type of technology, locations, capacity, etc., covering $15-50 \%$ of the total investment cost.

The subsidy mechanism seems to work well as some types of renewable power generation systems grow very much. Table 1 indicates that wind capacity in Taiwan grew more than 62-fold during 2004-2011, expanding substantially from $8.5 \mathrm{MW}$ in 2004 to $522.7 \mathrm{MW}$ in 2011. The share of wind power capacity in total renewable power increased from $0.1 \%$ in 2000 to $15.5 \%$ in 2010. Total wind power generation grew 1,066-fold, increasing from $1.4 \mathrm{GWH}$ in 2000 to $1,492.7 \mathrm{GWH}$ in 2011 , indicated in Table 2, and its share in total renewable electricity production increased dramatically from $0.02 \%$ in 2000 to $16.6 \%$ in 2011. Between 2000 and 2011, the installation of wind power systems produced 4,787 GWH and already reduced $\mathrm{CO} 2$ emissions by about 3.21 million tonnes.

The capacity of Taiwan's solar PV power systems also increased very much from $0.1 \mathrm{MW}$ in 2000 to $73.7 \mathrm{MW}$ in 2011, but its share in total renewable installed capacity and electricity generation by 2011 was still very low, reaching 2.2 and $0.75 \%$, respectively.

Until now, hydropower and electricity generated from waste-to-heat incineration facilities (EGWIF) have formed as the major constitution of renewable energy supply in Taiwan, shown in Table 2. In 2011, total renewable electricity generation amounts to $8,978.9 \mathrm{GWH}$, accounting to $3.56 \%$ of total power generation $(252,172.9 \mathrm{GWH})$. Among renewable electricity generation, hydropower supplied 3,999.7 GWH (44.5\%), EGWIF contributed to 3,091.9 GWH (34.4\%), wind power provided 1,492.7 GWH (16.6\%), biomass generated 327.2 (3.6\%), and solar PV power systems only $67.5 \mathrm{GWH}(0.75 \%)$.

Hydropower led the renewable electricity generation and installation capacity in Taiwan. It installed more than 2,040.7 MW, accounting for $60.5 \%$ of total renewable installations by end of 2011 . The hydropower production, however, dropped very much from 4,567.5 GWH in 2000 to $3,999.7 \mathrm{GWH}$ in 2011 due to the exhaustion of water resources. The share of hydropower installed capacity also kept a declining pattern, dropping very much from $80.4 \%$

Table 1 The cumulated installed capacity of renewable power systems in Taiwan

\begin{tabular}{rrrrrrrrrrrr}
\hline & Hydro & \multicolumn{3}{c}{ Wind } & & PV & & Biomass & & Waste & Total \\
\hline 2000 & $1,820.0$ & $80.4 \%$ & 2.6 & $0.1 \%$ & 0.1 & $0.0 \%$ & 85.1 & $3.8 \%$ & 354.7 & $15.7 \%$ & $2,262.5$ \\
2001 & $1,820.0$ & $74.5 \%$ & 5.0 & $0.2 \%$ & 0.2 & $0.0 \%$ & 90.6 & $3.7 \%$ & 527.6 & $21.6 \%$ & $2,443.4$ \\
2002 & $1,908.8$ & $75.7 \%$ & 8.5 & $0.3 \%$ & 0.3 & $0.0 \%$ & 90.6 & $3.6 \%$ & 512.4 & $20.3 \%$ & $2,520.6$ \\
2003 & $1,908.8$ & $75.3 \%$ & 8.5 & $0.3 \%$ & 0.5 & $0.0 \%$ & 103.1 & $4.1 \%$ & 512.4 & $20.2 \%$ & $2,533.3$ \\
2004 & $1,909.7$ & $74.5 \%$ & 8.5 & $0.3 \%$ & 0.6 & $0.0 \%$ & 103.1 & $4.0 \%$ & 541.8 & $21.1 \%$ & $2,563.7$ \\
2005 & $1,909.7$ & $73.2 \%$ & 23.9 & $0.9 \%$ & 1.0 & $0.0 \%$ & 99.1 & $3.8 \%$ & 573.8 & $22.0 \%$ & $2,607.5$ \\
2006 & $1,909.7$ & $69.7 \%$ & 102.0 & $3.7 \%$ & 1.4 & $0.1 \%$ & 116.8 & $4.3 \%$ & 609.5 & $22.3 \%$ & $2,739.3$ \\
2007 & $1,921.2$ & $67.4 \%$ & 186.0 & $6.5 \%$ & 2.4 & $0.1 \%$ & 116.8 & $4.1 \%$ & 622.5 & $21.9 \%$ & $2,848.8$ \\
2008 & $1,937.9$ & $66.1 \%$ & 250.4 & $8.5 \%$ & 5.6 & $0.2 \%$ & 116.8 & $4.0 \%$ & 622.5 & $21.2 \%$ & $2,933.1$ \\
2009 & $1,936.9$ & $63.3 \%$ & 374.3 & $12.2 \%$ & 9.5 & $0.3 \%$ & 116.8 & $3.8 \%$ & 622.5 & $20.3 \%$ & $3,059.9$ \\
2010 & $1,977.4$ & $61.5 \%$ & 475.9 & $14.8 \%$ & 21.3 & $0.7 \%$ & 116.8 & $3.6 \%$ & 622.5 & $19.4 \%$ & $3,213.8$ \\
2011 & $2,040.7$ & $60.5 \%$ & 522.7 & $15.5 \%$ & 73.7 & $2.2 \%$ & 111.3 & $3.3 \%$ & 624.4 & $18.5 \%$ & $3,372.9$ \\
\hline
\end{tabular}

Source BOE (2012), Unit: MW 
Table 2 The renewable electricity generation in Taiwan (2000-2010)

\begin{tabular}{llrlllll}
\hline Years & Hydro & \multicolumn{1}{c}{ Wind } & Solar PV & Biomass & Waste & Total renewable & Total power generation \\
\hline 2000 & $4,567.5$ & 1.4 & 0.1 & 352.4 & $1,480.1$ & $6,401.5$ & $184,862.0$ \\
2001 & $5,099.5$ & 12.2 & 0.3 & 339.0 & $2,009.9$ & $7,461.0$ & $188,540.9$ \\
2002 & $2,787.5$ & 15.9 & 0.3 & 382.9 & $2,545.9$ & $5,732.6$ & $198,837.5$ \\
2003 & $3,035.9$ & 23.8 & 0.5 & 376.4 & $2,632.8$ & $6,069.4$ & $209,071.8$ \\
2004 & $3,209.9$ & 25.3 & 0.6 & 362.9 & $2,824.7$ & $6,423.3$ & $218,396.6$ \\
2005 & $3,986.2$ & 91.3 & 1.0 & 336.4 & $2,853.0$ & $7,267.8$ & $227,364.3$ \\
2006 & $4,088.4$ & 276.1 & 1.5 & 385.2 & $2,902.4$ & $7,653.5$ & $235,464.7$ \\
2007 & $4,417.5$ & 439.5 & 2.2 & 609.1 & $3,014.2$ & $8,482.6$ & $243,120.0$ \\
2008 & $4,305.1$ & 588.3 & 4.6 & 486.2 & $2,934.6$ & $8,318.7$ & $238,314.1$ \\
2009 & $3,748.3$ & 786.6 & 9.2 & 494.7 & $2,907.0$ & $7,945.8$ & $229,694.0$ \\
2010 & $4,194.1$ & $1,026.3$ & 25.5 & 539.5 & $3,036.1$ & $8,821.5$ & $247,045.4$ \\
2011 & $3,999.7$ & $1,492.7$ & 67.5 & 327.2 & $3,091.9$ & $8,978.9$ & $252,172.9$ \\
\hline
\end{tabular}

Source BOE (2012), Unit: GWH

in 2000 to $60.5 \%$ in 2011. This implies that hydropower may lose its leading role in supplying renewable electricity in the future.

EGWIF also provided an obvious contribution to renewable electricity production and was seen as a considerable potential for biomass energy development in Taiwan. Its production increased from 1,480 GWH in 2000 to $3,091.9 \mathrm{GWH}$ in 2011 , and its installed capacity reached $624.4 \mathrm{MW}$ by end of 2011 with share of $18.5 \%$. Due to the awareness of environmental consciousness, municipal solid waste (MSW) generation has decreased, and its consequence leads to a continual reduction in the expansion of MSW incineration facilities (Chen and Chen 2008; Chen 2010). Thus, the installed capacity of WTE plants has remained constant since 2007. This implies that the growth in electricity generation from waste heat is pessimistic.

The growth of biomass electricity production is not as attractive as wind power. The power generation from biomass increased from $352.4 \mathrm{GWH}$ in 2000 to $327.2 \mathrm{GWH}$ in 2011. Table 1 demonstrates that the installed capacity of biomass generation reached $116.8 \mathrm{MW}$ by 2006 and did not increase from then on. In practice, the consumption of biomass will crowd out the land use for food harvesting or the other applications. For example, the growing trees and other plants would remove $\mathrm{CO} 2$ from the atmosphere during photosynthesis and store the carbon in plant structure.

The above analysis releases that the installation capacity of hydropower and EGWIF may remain unchanged. Wind power is the most promising one to develop renewable energies in Taiwan as its share in the renewable electricity production increased from $0.02 \%(1.4 \mathrm{GWH})$ in 2000 to $16.5 \%(1,492.7 \mathrm{GWH})$ in 2011 . During the period of 2007-2011, the production of wind power and solar PV power grows much more than other renewable resources. The average growth rate of wind power generation is
$47.92 \%$ annually in the past 5 years. In contrast, the annual growth rate of solar PV power generation is also very high, reaching sixfold, but the share of solar photovoltaic (PV) generation is still very negligible, about $0.75 \%$ of renewable electricity generation in 2011. This implies that a large room exists for solar PV power generation to expand. Therefore, the development strategy of renewable electricity generation has to focus on the solar PV and wind power since the power generation technology for solar PV and wind power systems is still emerging and may work as a leading renewable energy supply in the future.

Based on the historical data and growth pattern, we derive two scenarios for the future development of renewable power installations by assuming the continuation of FIT policies for the coming years, including (1) the Moderate Scenario and (2) the Optimistic Scenario. A market "business-as-usual" market is assumed in the Moderate Scenario, and thus, no extra reform of existing operating renewable policies is adopted. Taiwan's growth pattern may follow the past experience, but only focusing on wind power and solar PV systems. The growth of other renewable resources is assumed to be zero.

MacKenzie (2003) proposes an analytical approach based on a universal logistic growth curve to establish the minimum fraction of each country's $\mathrm{CO}_{2}$ emissions that can arise from non-fossil sources. He argues that the thrust of his proposal is that "every country would follow the same requirements curve and would have to arrange its energy supply and demand so that the minimum percentage indicated would come from non-fossil sources such as solar, photovoltaic, wind, geothermal, biomass, and nuclear." (p. 1184). As Germany is a leading country in both solar PV electricity and wind power production, this paper selects Germany as a benchmark. The higher public participation in Germany may bring about higher growth rate 
of solar PV systems and wind power installations. However, Taiwan as a newly emerging market falling in the growing stage of product life cycle may accelerate its installation of renewable power, while Germany market is probably categorized as a maturated market. Considering all these aspects, the Germany growth pattern for Taiwan's projection may be useful and reliable. Hence, the Moderate Scenario assumes that the growth pattern of Taiwan's PV and wind power installation completely follows Germany if the feed-in tariff is kept stable and will not decrease in the future.

On the other hand, the Optimistic Scenario assumes that the government will strongly motivate the power generation of renewable energies and remove the possible barriers arising from administration units. The support mechanisms of the FIT policies will continue. In addition to the growth of wind power and solar PV systems, the other possibility to increase the renewable power supply is to develop the biomass power generation. The installation capacity of Taiwan's biomass power generation increased from 85.1 MW in 2000 to $111.3 \mathrm{MW}$ in 2011, with growth rate of $46.54 \%$. We assume that the FIT policy may stimulate the investment of biomass power generation with growth rate, doubling the past, that is, $93.08 \%$ in 10 years. And thus, the Optimistic Scenario assumes a double growth rate of the Moderate Scenario for wind power and solar PV installations and a double growth rate of Taiwan's historical evolution for the biomass energy.

\section{Results and discussion}

The renewable electricity generation in some leading countries

The renewable electricity generation for some selected countries in 2008 is listed in Table 3 according to the statistics databases of International Energy Agency (IEA 2011). China totally generated 600,797 GWH (gigawatt hour) of renewable electricity in 2008, ranked the top in the world. Its hydroelectric power generation contributed the major share of renewable electricity generation, attaining to $97.4 \%$ of total renewable electricity production. In contrast, the share of non-hydro renewable generation is relatively low. Under such a case, China still enjoys the relative advantage of hydro resource and plans to expand its investment on the hydropower projects. The Three Gorges Dam along the Yangtze River is still under construction, including 32 separate $700 \mathrm{MW}$ generators, for a total of $22.5 \mathrm{GW}$. The low share of non-hydro renewable energy supply implies that a large room exists for China to develop the non-hydro renewable energy like solar PV and wind power in the future. Currently, the share of solar PV power generation is still very negligible in China. Compared to EU, the USA, and Japan, China's PV power generation falls far behind. By 2010, China had installed about 893 MW of solar PV power systems, accounting for $2.29 \%$ of the world's capacity (EPIA 2011a) and started to implement FIT in July 2011 to meet a goal of $5 \mathrm{GW}$ by 2015 and $20 \mathrm{GW}$ by 2020 for the solar PV installations (EPIA 2011b).

The USA and Canada followed after China for renewable power supply, generating 429,546 and 394,920 GWH of renewable electricity in 2008, respectively. However, the USA led the world for the generation of wind power in 2008, contributing to 55,696 GWH, ahead of Germany and Spain that produced 40,574 and 32,203 GWH, respectively. In Canada, hydropower contributed $89.1 \%$ of total renewable power supply in 2008 due to the abundant hydropower potential. Canada's hydro electricity production reached $382,580 \mathrm{GWH}$ in 2008, ranked the second place in the world. Japan and Germany have implemented FIT policies earlier to encourage the renewable power generation, and thus, the two countries have achieved a relatively stable market than other countries. In 2008, the two countries generated 113,309 GWH and 101,194 GWH of renewable electricity, respectively.

Table 3 Gross renewable electricity generation from selected countries in 2008

\begin{tabular}{|c|c|c|c|c|c|c|c|c|}
\hline & Waste & Biomass & Geo-thermal & Hydro & Solar PV & Tide, etc. & Wind & Total \\
\hline China & 0 & 2,359 & 0 & 585,187 & 172 & 0 & 13,079 & 600,797 \\
\hline The USA & 22,190 & 50,201 & 17,014 & 281,995 & 1,572 & 0 & 55,696 & 429,546 \\
\hline Canada & 157 & 8,298 & 0 & 382,580 & 33 & 33 & 3,819 & 394,920 \\
\hline Japan & 7,309 & 15,079 & 2,752 & 83,295 & 2,251 & 0 & 2,623 & 113,309 \\
\hline Germany & 9,368 & 19,851 & 18 & 26,963 & 4,420 & 0 & 40,574 & 101,194 \\
\hline France & 3,776 & 2,116 & 0 & 68,325 & 41 & 513 & 5,689 & 80,460 \\
\hline Italy & 3,255 & 4,409 & 5,520 & 47,227 & 193 & 0 & 4,861 & 65,465 \\
\hline Spain & 1,564 & 2,473 & 0 & 26,112 & 2,562 & 0 & 32,203 & 64,930 \\
\hline The UK & 2,871 & 8,090 & 0 & 9,257 & 17 & 0 & 7,097 & 27,332 \\
\hline
\end{tabular}

Source IEA (2011), Unit: GWH 
Table 3 demonstrates that hydropower dominated the renewable power generation in many countries and the contribution of wind power ranked the second place in 2008. In fact, wind power and solar PV power grow rapidly and become more and more important presently. By 2009, the USA still leaded the world for wind power generation with the highest wind power capacity of $35 \mathrm{GW}$, ahead of China's 25.853 MW and Germany's 25.777 GW (please see Table 4). However, the wind power capacity additions in the USA dropped to the second place in the world in 2009 , capturing roughly $26 \%$ of the worldwide market, while China's seized $36 \%$ market share (Wiser and Bolinger 2010). China has become the first place for the new installation of wind power in the world since 2009.

Total Europe by end of 2010 had installed 86,321 MW of wind power systems, among which 84,324 MW were installed in European Union, accounting for $98.83 \%$. Table 5 lists the wind capacity of the top 10 countries in EU during 2008-2010 and demonstrates that Germany has leaded EU in the development of the wind energy since early 2000s. Germany installed approximately 27, $214 \mathrm{MW}$ with $32.27 \%$ of shares by end of 2010, while Spain kept a closed pace with Germany, ranking the second with cumulative capacity of 20,676 MW, accounting for $24.52 \%$ of EU's wind power markets. The market for wind power other than Germany and Spain is much less. For example, Italy, ranking the third place, had installed only $5,795 \mathrm{MW}$, accounting for $6.87 \%$ of the whole EU market by end of 2010 (Table 5).

As to solar PV electricity generation, Table 3 indicates that Germany contributed the most in 2008, generating 4,420 GWH and Spain followed, producing 2,562 GWH. According to ESTELA (2009), more than $500 \mathrm{MW}$ of solar PV power systems would be connected to the grid for EU countries by 2010 . The share of solar PV electricity could contribute to $20 \%$ of electricity generation by 2020 . EPIA (2011a) points out that approximately 15,000 MW of new solar PV systems was installed in 2010 in the world, and

Table 4 The installed wind capacity for the selected countries

\begin{tabular}{|c|c|c|c|c|c|c|c|}
\hline & $2005^{\mathrm{a}}$ & $2006^{\mathrm{a}}$ & $2007^{\mathrm{a}}$ & $2008^{a}$ & $2008^{b}$ & $2009^{b}$ & $2010^{b}$ \\
\hline The USA & 8.706 & 11.329 & 16.515 & 24.651 & - & $35.000^{\mathrm{c}}$ & - \\
\hline China & 1.260 & 2.599 & 5.912 & 12.170 & - & $25.853^{c}$ & - \\
\hline Germany & 18.428 & 20.622 & 22.247 & 23.895 & 23.860 & 25.777 & 27.214 \\
\hline Spain & 9.918 & 11.722 & 14.779 & 16.546 & 16.701 & 19.160 & 20.676 \\
\hline Italy & 1.635 & 1.902 & 2.702 & 3.525 & 3.735 & 4.849 & 5.795 \\
\hline France & 0.723 & 1.412 & 2.220 & 3.422 & 3.486 & 4.574 & 5.660 \\
\hline The UK & 1.565 & 1.955 & 2.477 & 3.406 & 2.974 & 4.245 & 5.204 \\
\hline Canada & 0.684 & 1.460 & 1.770 & 2.369 & - & - & - \\
\hline Japan & 1.227 & 1.805 & 1.527 & 1.756 & - & - & - \\
\hline
\end{tabular}

a Source EIA (2011)

b Source EWEA (2011a)

c Source Wiser and Bolinger (2010), Unit: GW

Table 5 The installed wind capacity of top 10 countries in EU-27 (2008-2010)

\begin{tabular}{|c|c|c|c|c|c|c|}
\hline & End 2008 (MW) & End 2009 (MW) & End $2010(\mathrm{MW})$ & Share in 2008 & Share in 2009 & Share in 2010 \\
\hline Germany & 23,860 & 25,777 & 27,214 & 0.3679 & 0.3432 & 0.3227 \\
\hline Spain & 16,701 & 19,160 & 20,676 & 0.2575 & 0.2551 & 0.2452 \\
\hline Italy & 3,735 & 4,849 & 5,795 & 0.0576 & 0.0646 & 0.0687 \\
\hline France & 3,486 & 4,574 & 5,660 & 0.0537 & 0.0609 & 0.0671 \\
\hline The United Kingdom & 2,974 & 4,245 & 5,204 & 0.0459 & 0.0565 & 0.0617 \\
\hline Portugal & 2,862 & 3,535 & 3,898 & 0.0441 & 0.0471 & 0.0462 \\
\hline Denmark & 3,131 & 3,465 & 3,798 & 0.0483 & 0.0461 & 0.0450 \\
\hline The Netherlands & 2,176 & 2,215 & 2,245 & 0.0336 & 0.0295 & 0.0266 \\
\hline Sweden & 1,048 & 1,560 & 2,163 & 0.0162 & 0.0208 & 0.0257 \\
\hline Ireland & 1,077 & 1,310 & 1,428 & 0.0166 & 0.0174 & 0.0169 \\
\hline Total & 64,857 & 75,103 & 84,324 & 1 & 1 & 1 \\
\hline
\end{tabular}

Source EWEA (2011a), Unit: MW 


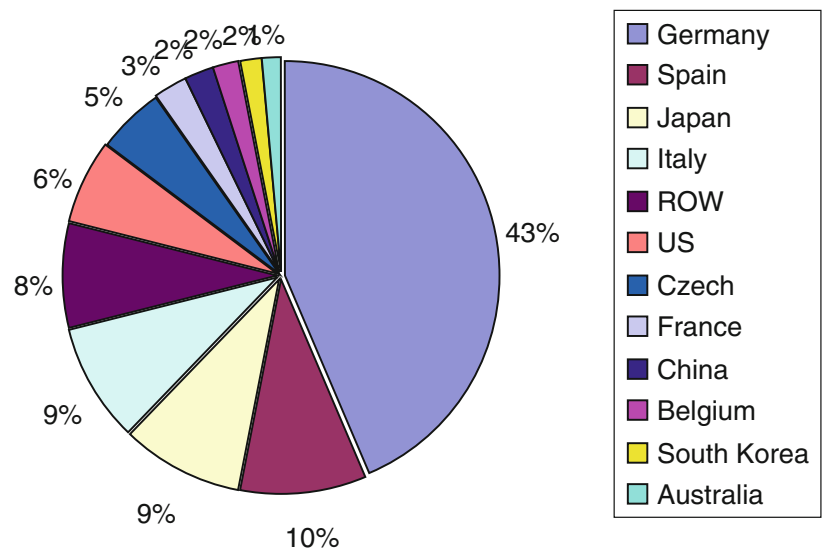

Fig. 1 The cumulative PV capacity for the selected leading countries through 2010

the accumulated capacity reached 40,000 MW. The data shown on Page 10 of EPIA (2011a) demonstrate that EU may continue to lead solar PV power generation with over $70 \%$ of global installation capacity (EPIA 2011a).

Figure 1 depicts the cumulative PV capacity of the leading countries through 2010. Among these countries, Germany stood at an outstanding position for the promotion of solar PV electricity generation and had been far ahead of other countries for the production of solar PV electricity. Spain, Japan, and Italy ranked the second, third, and fourth place in the world, respectively, but all of them kept a large distance from Germany. The share of German's PV installation in the world was $43.49 \%$, much higher than Spain's $9.57 \%$, Japan's $9.16 \%$, and Italy's $8.84 \%$ by end of 2010. Table 6 demonstrates the historical development of PV capacity in these selected countries. German's cumulative capacity reached 2,899 MW in 2006, accounting for $41.43 \%$ of the global installation capacity, ahead of Japan's 1,708 MW, the USA's $624 \mathrm{MW}$ and other countries. The average growth rate of installation capacity in Germany reached 56.65 \% during 2006-2010, still little higher than the world's growth rate of $54.95 \%$ (please see Table 6). EPIA (2011a) indicates that Germany by 2010 had installed 17,193 MW of solar PV power systems, accounting for $58.77 \%$ of EU installation capacity $(29,252 \mathrm{MW})$, and $43.49 \%$ of the global installation capacity $(39,529 \mathrm{MW})$. In 2010, Germany is the largest producer for solar PV electricity with output of $12 \mathrm{TWH}$. By 2015, Germany will reach a cumulative installation capacity of 42,200 MW.

The high success of Germany solar PV installation may attribute to its feed-in tariff policy, starting from January 1, 1991, when the "Electricity Feed Law (EFL)" was effective. In April 2000, it was revised and replaced by a new act called the "Renewable Energies Law" (REL). The grid companies are obliged to purchase renewable electricity from eligible sources at an annually fixed feed-in tariff. Without a doubt, the feed-in tariff policy implemented in Germany has contributed a substantial consequence of renewable electricity production as a share of about $14 \%$ of total electricity production was attained in 2008 , exceeding its goal of at least $12.5 \%$ set for 2010. In 2009, Germany amended the Renewable Energy Sources Act that sets feedin tariffs to be EUR cents $43.01 / \mathrm{KWH}$ up to $30 \mathrm{KW}, 40.91$ from 30 to $100 \mathrm{KW}, 39.58$ from $100 \mathrm{KW}$ to $1 \mathrm{MW}$, and 33 over $1 \mathrm{MW}$ for roof-mounted facilities, and EUR cents 31.94/KWH for free-standing facilities (IEA 2011).

Spain had installed 3,784 MW by end of 2010, ranked the second place in the world for solar PV installations, but far behind Germany's 17,193 MW. A large portion of Spain's solar PV power systems was installed during the period of 2007-2008 when generous feed-in tariffs were implemented. In the early 2000s, feed-in tariffs in Spain played a prominent role in stimulating solar PV electricity generation. The growth rate of Spain's solar PV power system increased 3.6-fold and 3.9-fold in 2007 and 2008, respectively, but it dropped to $0.5 \%$ in 2009 and $10.8 \%$ in 2010. After 2009, the annual installation rate of solar PV power systems in Spain fell behind a lot of countries, such as Italy, France, China, Japan, and the USA because of decreased feed-in tariffs. The decline after 2009 may attribute to the 2009 global finance disaster and the reduction in feed-in tariffs that decreased by $50 \%$ in 2009. Compared to Germany that kept a stable growth of installation capacity, Spain had a fluctuating growth pattern.

Similar to the growth pattern of Germany, the installation capacity of Japan's solar PV power systems grew stably, increasing from 1,708 MW by 2006 to 3,622 MW by 2010 with average growth rate of $21.10 \%$, much lower than other leading countries and world's average level. Based on the growth pattern, Japan's solar PV installations may be taken over by other countries like Italy very soon. The tragic disaster of the Fukushima nuclear power plant occurred in 2011 may affect Japan's energy policy and provide a brighter prospect for solar PV power plants and other renewable energies.

Compared to its high demand for energies, the USA installed few solar PV power systems. By 2010, the cumulative capacity reached 2,528 MW, ranked the fifth place in the world, far behind other leading countries. The growth rate in the USA was only $42.05 \%$, lower than the world's average level. This implies that a large room exists for the USA to deploy the solar PV power generation.

The outcome of Taiwan's renewable energy policy

As time passes, some of these goals are proved to be a dream. Table 2 indicates that renewable electricity generation by end of 2010 reached $8,821.5 \mathrm{GWH}$, including 
Table 6 The cumulative installation capacity of solar PV power systems for the selected countries (2006-2010)

\begin{tabular}{|c|c|c|c|c|c|c|}
\hline Years & 2006 & 2007 & 2008 & 2009 & 2010 & Average growth rate (2008-2010) \\
\hline Germany & $\begin{array}{l}2,899 \\
(543)^{\mathrm{a}}\end{array}$ & $\begin{array}{l}4,170 \\
(1,271)\end{array}$ & $\begin{array}{l}5,979 \\
(1,809)\end{array}$ & $\begin{array}{l}9,785 \\
(3,808)\end{array}$ & $\begin{array}{l}17,193 \\
(7,408)\end{array}$ & 0.5665 \\
\hline Spain & $\begin{array}{l}148 \\
(102)\end{array}$ & $\begin{array}{l}690 \\
(542)\end{array}$ & $\begin{array}{l}3,398 \\
(2,708)\end{array}$ & $\begin{array}{l}3,415 \\
(17)\end{array}$ & $\begin{array}{l}3,784 \\
(369)\end{array}$ & 1.9249 \\
\hline Japan & $\begin{array}{l}1,708 \\
(286)\end{array}$ & $\begin{array}{l}1,919 \\
(211)\end{array}$ & $\begin{array}{l}2,149 \\
(230)\end{array}$ & $\begin{array}{l}2,632 \\
(483)\end{array}$ & $\begin{array}{l}3,622 \\
(990)\end{array}$ & 0.2110 \\
\hline Italy & $\begin{array}{l}47 \\
(10)\end{array}$ & $\begin{array}{l}117 \\
(70)\end{array}$ & $\begin{array}{l}456 \\
(338)\end{array}$ & $\begin{array}{l}1,173 \\
(717)\end{array}$ & $\begin{array}{l}3,494 \\
(2,321)\end{array}$ & 1.9844 \\
\hline The USA & $\begin{array}{l}624 \\
(145)\end{array}$ & $\begin{array}{l}831 \\
(207)\end{array}$ & $\begin{array}{l}1,173 \\
(342)\end{array}$ & $\begin{array}{l}1,650 \\
(477)\end{array}$ & $\begin{array}{l}2,528 \\
(878)\end{array}$ & 0.4205 \\
\hline France & $\begin{array}{l}30 \\
(8)\end{array}$ & $\begin{array}{l}41 \\
(11)\end{array}$ & $\begin{array}{l}87 \\
(46)\end{array}$ & $\begin{array}{l}306 \\
(219)\end{array}$ & $\begin{array}{l}1,025 \\
(719)\end{array}$ & 1.5888 \\
\hline The UK & $\begin{array}{l}1 \\
(1)\end{array}$ & $\begin{array}{l}5 \\
(4)\end{array}$ & $\begin{array}{l}11 \\
(6)\end{array}$ & $\begin{array}{l}21 \\
(10)\end{array}$ & $\begin{array}{l}66 \\
(45)\end{array}$ & 2.0630 \\
\hline Canada & $\begin{array}{l}21 \\
(4)\end{array}$ & $\begin{array}{l}26 \\
(5)\end{array}$ & $\begin{array}{l}33 \\
(7)\end{array}$ & $\begin{array}{l}95 \\
(62)\end{array}$ & $\begin{array}{l}200 \\
(105)\end{array}$ & 0.8728 \\
\hline China & $\begin{array}{l}80 \\
(12)\end{array}$ & $\begin{array}{l}100 \\
(20)\end{array}$ & $\begin{array}{l}145 \\
(45)\end{array}$ & $\begin{array}{l}373 \\
(228)\end{array}$ & $\begin{array}{l}893 \\
(520)\end{array}$ & 0.9166 \\
\hline World & $\begin{array}{l}6,980 \\
(1,581)\end{array}$ & $\begin{array}{l}9,492 \\
(2,513)\end{array}$ & $\begin{array}{l}15,655 \\
(6,168)\end{array}$ & $\begin{array}{l}22,900 \\
(7,257)\end{array}$ & $\begin{array}{l}39,529 \\
(16,629)\end{array}$ & 0.5495 \\
\hline
\end{tabular}

Source EPIA (2011a), Unit: MW

${ }^{\text {a }}$ Brackets refer to the annual installation capacity

4,194.1 GWH hydropower, 1,026.3 GWH wind power, 25.5 GWH solar PV electricity, 539.5 GWH biomass, and 3,036.1 GWH EGWIF. Compare to total power generation of $247,045 \mathrm{GWH}$, the share of renewable power generation in 2010 was only $3.57 \%$, much less than the goal of $10 \%$. The total installed capacity of renewable power generation system by end of 2010 reached 3,213.8 MW, accounting for $6.57 \%$ of total power capacity only.

The fact shows that Taiwan's $10 \%$ renewable electricity goal by 2010 is proved to be a failure, and the goals mentioned in MOEA (2005) that planned to install more than 5,130 MW of renewable power generation systems by 2010 also completely fail. Among the renewable power installations, the goals for wind power and solar PV power regulated by MOEA (2005) are also proved to be unable to meet the goals. By end of 2010, the total installed capacity of wind power in Taiwan stood at 475.9 MW, falling far behind the goal of 2,159 MW.

Even though the policy goals are proved to fail, the past renewable energy policy with financial supporting mechanisms has contributed to environmental improvements with limited success. Taiwan government still keeps a positive and optimistic manner for the development of renewable energies. Based on the past experience in promoting the renewable electricity generation, the policy makers released more clear signals to stipulate more investors for the installations of renewable energy projects. In 2009, Taiwan enacted a new feed-in tariff mechanism called "Directive for promoting renewable energies (DPRE)" that focus on the financial subsidy to the renewable electricity generation through the implementation of feed-in tariffs. The subsidy for the investment costs regulated in the previous laws remains valid. Article 6 of the DPRE sets an overall goal that expects $6,500-10,000 \mathrm{MW}$ of new renewable power systems to be installed. According to the DPRE, TPC (the power monopoly in Taiwan) is obliged to purchase the electricity generated from IPPs at the regulated price (feedin tariff $^{1}$ ) for a guaranteed period of time. And thus, the solar PV systems should be connected to the grid and serving as a power supply source through the electricity distribution network. A separate meter is required to install to track the output of the solar PV power system.

The feed-in tariffs implemented in Taiwan are fixed at a certain level over the guaranteed period and determined by the government without any direct relation to the retail price

\footnotetext{
${ }^{1}$ In this paper, the term "feed-in tariff" is used for the total amount per KWH received by an independent producer of solar PV electricity, paid by the government attorney (Taiwan Power Company).
} 
Table 7 Feed-in tariffs implemented in Taiwan

\begin{tabular}{lc}
\hline & Range of categorized capacity \\
\hline Solar PV & \\
$1-10 \mathrm{KW}$ & 10.3185 \\
$10-100 \mathrm{KW}$ & 9.1799 \\
$100-500 \mathrm{KW}$ & 8.8241 \\
$>500 \mathrm{KW}$ & 7.9701 \\
Wind (onshore) & \\
$1-10 \mathrm{KW}$ & 7.3562 \\
$\quad>10 \mathrm{KW}$ & 2.6138 \\
Wind (offshore) & 5.5626 \\
Biomass & 2.1821 \\
Geothermal & 4.8039 \\
Hydropower & 2.1821 \\
Waste energy & 2.6875 \\
\hline
\end{tabular}

Unit: $(\mathrm{NT} \$ / \mathrm{KWH})$

of electricity. Article 9 of the DPRE regulates that the level of feed-in tariffs should be reviewed every year by the "tariff reviewing committee" and revised in light of technological development of power generating system, the cost change, and policy goals. As of early 2011, the feed-in tariffs were determined and announced, listed in Table 7 that reflects the cost situation of the renewable electricity generation technology. The feed-in tariff for the solar PV electricity is the highest, ranged from NT\$ 7.9701 to 10.3185 per KWH while NT\$ 4.8309 per KWH is offered for geothermal electricity and NT\$2.6138-7.3562 per $\mathrm{KWH}$ for wind power (on shore). Compared to onshore wind power, the support level for offshore wind power is significantly increased to NT\$ 5.5626 due to the high investment risks of offshore wind power installations (please see Table 7).

The FIT policy provides high financial incentives for renewable electricity generation and highly reduces the investment risks as the payment is predetermined for the period of guarantee payments that is valid for 20 years in Taiwan. In practice, a great number of countries have adopted FIT policies to promote the installation of renewable power generation in the world. According to EPIA (2011b), the following countries have feed-in tariffs in place: China (partly), Japan, Canada, Austria, Belgium, Denmark, Finland, France, Germany, Greece, Luxembourg, Portugal, Spain, and Sweden. The relevant description involving the FIT policies of some selected countries is listed in Table 8.

The tariffs implemented in Germany are the highest in the world in the past few years according to IEA (2011). As of January 2009, the Renewable Energy Sources Act (EEG) was revised and came into force. After then, the feed-in tariff for onshore wind farms was increased from
EUR cents 8.03 to 9.2/kilowatt-h (KWH) for the first 5 years of operation and EUR cents $5.02 / \mathrm{KWH}$ after that. Compared to Taiwan's NT 2.6138 (EUR cents 6.53) implemented after 2011, Germany still provided higher feed-in tariff for wind power than Taiwan. In contrast, Germany's feed-in tariff for solar PV electricity is decreasing continually. Even though, the tariff of EUR cents 35.31 is still higher than Taiwan's average feed-in tariff of NT\$ 9.07 (EUR cents 22.67) for PV electricity.

Germany has performed a dramatic increase in PV installation capacity, increasing from 2,056 MW in 2005 to 17,193 MW in 2010 (EPIA 2011a), growing 8.36-fold in 5 years. As to wind power installation, it increased from $18,428 \mathrm{MW}$ in 2005 to 27,214 MW in 2010, with growth rate of $47.7 \%$ in 5 years. While most Western countries have promoted PV as part of their larger strategies to address various environmental and energy security issues, Taiwan has attempted to catch up with the future trend of PV installation capacity in the grid-connected small residential system category. Considering the high similarity of FIT policies, we employ the growth pattern of Germany as a benchmark for Taiwan to project its future deployment of renewable power systems in this paper.

\section{Outlook on Taiwan's renewable power goals}

The outlook of the two scenarios is listed in Table 9 for the future development of Taiwan's renewable power generation. The Moderate Scenario demonstrates that Taiwan's total renewable power installation capacity may increase from 5,813.8 MW in 2010 to 7,245.99 MW in 2030. The total increase in the new installation capacity attain to 1,432.19 MW, much lower than Taiwan government's goal (a new installation of 6,500-10,000 MW for renewable power generation systems). The result of the Optimistic Scenario shows that the total renewable power installation capacity may increase from 5,813.8 MW in 2010 to 11,977.14 MW in 2030. The total increase in the new installation capacity attain to $6,163.664 \mathrm{MW}$ that slightly less than the goal.

Table 9 shows Taiwan may install more power generation systems up to $770.45,1,540.91,3,081.82$, and 6,163.64 MW by 2015, 2020, 2025, and 2030, respectively, where wind power and solar PV power generation provide a substantial contribution for the capacity increase in newly installed capacity. Among the renewable power, wind power and solar PV electricity may be more feasible to develop for the attainment of the goal for the installation of 6,500-10,000 MW new capacity in Taiwan. It is estimated that new installation capacities will be 458.5, 916.99, 1,833.98, and 3,667.97 MW for wind power, and 257.6, 515.2, 1,030.4, and 2,060.8 MW for solar PV electricity by 2015, 2020, 2025, and 2030, 
Table 8 The comparison of FIT policies for solar PV electricity generation implemented in the selected countries

\begin{tabular}{|c|c|c|}
\hline & Policy title & Description \\
\hline China & Interim feed-in tariff for four Ningxia solar projects & $\begin{array}{l}\text { A special feed-in tariff of CNY } 1.15 / \mathrm{kWh} \text { (equivalent to USD } 0.18 \text { ) is set } \\
\text { up for four PV power plants with total capacity of } 40 \mathrm{MW} \text { in the } \\
\text { Ningxia province }\end{array}$ \\
\hline Japan & $\begin{array}{l}\text { New purchase system for solar power-generated } \\
\text { electricity }\end{array}$ & $\begin{array}{l}\text { Utilities are obliged to purchase the excess electricity generated from } \\
\text { households at a rate of JPY 48/kWh (equivalent to USD 0.51), and from } \\
\text { non-household sources (e.g., schools and hospitals) at JPY 24/kWh }\end{array}$ \\
\hline Germany & $\begin{array}{l}\text { Amendment of the Renewable Energy Sources Act } \\
\text { (EEG) }\end{array}$ & $\begin{array}{l}\text { Feed-in tariffs are EUR cents } 43.01 / \mathrm{kWh} \text { (equivalent to USD 0.56) up to } \\
30 \mathrm{~kW}, 40.91 \text { (USD } 0.54 \text { ) from } 30 \text { to } 100 \mathrm{~kW}, 39.58 \text { (USD } 0.52 \text { ) from } \\
100 \mathrm{~kW} \text { to } 1 \mathrm{MW} \text {, and } 33 \text { (USD } 0.43 \text { ) over } 1 \mathrm{MW} \text { for roof-mounted } \\
\text { facilities, and EUR cents } 31.94 / \mathrm{kWh} \text { (USD 0.42) for free-standing } \\
\text { facilities } \\
\text { A new tariff of EUR cents } 25.01 / \mathrm{kWh} \text { (USD } 0.33 \text { ) was introduced for } \\
\text { systems up to } 30 \mathrm{~kW} \text { when electricity produced is used within the } \\
\text { building or facility in the revised law }\end{array}$ \\
\hline Spain & $\begin{array}{l}\text { New regulation on electrical energy from wind and } \\
\text { thermal electric technologies (Royal Decree } \\
1614 / 2010 \text { ) }\end{array}$ & $\begin{array}{l}\text { The period of guarantee payment is } 25 \text { years for solar PV power plants. } \\
\text { The existing feed-in tariffs will be cut down by: } \\
5 \% \text { for small-size roof installations. Tariffs will decrease from EUR } \\
320 / \text { MWh (equivalent to USD } 420 \text { ) to EUR 304/MWh (USD 399) } \\
25 \% \text { for medium-size ( } 21 \text { to } 100 \mathrm{~kW} \text { ) roof installation. Tariffs will } \\
\text { decrease from EUR 286/MWh (USD 376) to EUR 215/MWh. (USD } \\
282 \text { ) } \\
45 \% \text { for ground installations. Tariffs will decrease from EUR 258/MWh } \\
\text { (USD 339) to EUR 142/MWh. (USD 187) }\end{array}$ \\
\hline France & Renewable energy feed-in tariff: solar PV & 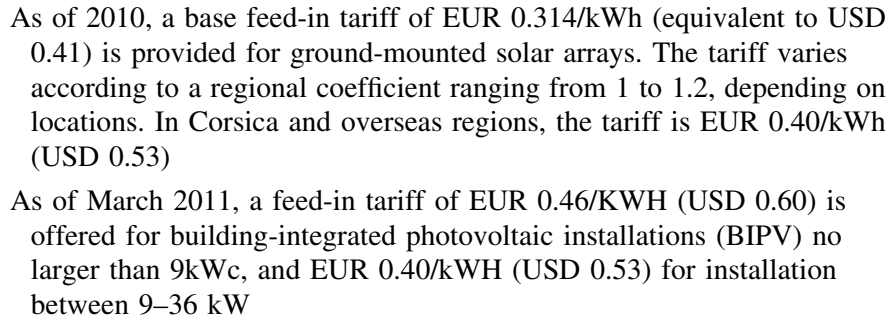 \\
\hline Italy & New feed-in premium for photovoltaic systems & $\begin{array}{l}\text { The period of guarantee payment is } 20 \text { years for the PV systems entering } \\
\text { service after } 12 / 31 / 2010 \text { and before } 12 / 31 / 2011 \text {. A bonus is offered in } \\
\text { addition to a given set of tariffs in case of innovative technologies of } \\
\text { integration of photovoltaic in buildings }\end{array}$ \\
\hline The UK & Feed-in tariffs for renewable electricity & $\begin{array}{l}\text { Electricity suppliers are obliged to purchase the electricity from } \\
\text { renewable resources with following level of tariffs that is valid until } \\
\text { March } 2013 \text { in GBP pence/kWh (which will be adjusted for inflation): } \\
\text { solar PV ( } 25 \text { years) } \\
\text { Under } 4 \mathrm{~kW} \text { (new build) and 4-10 kW: } 36.1,33.0 \text { (equivalent to USD } \\
\text { 0.54, 0.50) from April 2012-March 2013; } \\
\text { Under } 4 \mathrm{~kW} \text { (retrofit): } 41.3 \text { and } 37.8 \text { (USD 0.62, 0.57) from April 2012- } \\
\text { March 2013; } \\
\text { 10-100 kW: } 31.4,28.7 \text { (USD 0.47, 0.43) from April 2012-March 2013; } \\
100 \mathrm{kW-5} \mathrm{MW} \mathrm{and} \mathrm{stand-alone} \mathrm{system:} 29.3,26.8 \text { (USD 0.44, 0.40) } \\
\text { from April 2012-March } 2013\end{array}$ \\
\hline Canada & Ontario feed-in tariff programme & $\begin{array}{l}\text { Ontario's Feed-in Tariff (FIT) programme offers a fixed tariff for } \\
\text { electricity produced and fed into the electricity grid. FIT payments vary } \\
\text { across capacity size, up to } 80.2 \mathrm{CAD} \phi / \mathrm{kWh} \text { (equivalent to USD } 0.79 \text { ) } \\
\text { for residential solar rooftop projects } 10 \mathrm{~kW} \text { or smaller }\end{array}$ \\
\hline
\end{tabular}

Source IEA (2011)

respectively. In contrast, the new installation of the biomass power generating system is only 54.36, 108.72, 217.43, and 434.87 MW by 2015, 2020, 2025, and 2030, respectively. In 2030, hydropower will still dominate the renewable power market, but its share of installed capacity will decline from $78.77 \%$ in 2010 to $38.23 \%$ 
Table 9 The moderate and optimistic scenario for the outlook on the installed capacity of Taiwan's renewable power systems. Unit: MW

\begin{tabular}{|c|c|c|c|c|c|c|}
\hline & Scenario & 2010 & 2015 & 2020 & 2025 & 2030 \\
\hline \multirow[t]{2}{*}{ Hydro } & Mod. & $4,579.40$ & $4,579.40$ & $4,579.40$ & $4,579.40$ & $4,579.40$ \\
\hline & Optim. & $4,579.40$ & $4,579.40$ & $4,579.40$ & $4,579.40$ & $4,579.40$ \\
\hline \multirow[t]{2}{*}{ Wind } & Mod. & 477.60 & 706.85 & 936.10 & $1,165.34$ & $1,394.59$ \\
\hline & Optim. & 477.60 & 936.10 & $1,394.59$ & $2,311.58$ & $4,145.57$ \\
\hline \multirow[t]{2}{*}{ PV } & Mod. & 17.50 & 146.30 & 275.10 & 403.90 & 532.70 \\
\hline & Optim. & 17.50 & 275.10 & 532.70 & $1,047.90$ & $2,078.30$ \\
\hline \multirow[t]{2}{*}{ Biomass } & Mod. & 116.80 & 116.80 & 116.80 & 116.80 & 116.80 \\
\hline & Optim. & 116.80 & 171.16 & 225.52 & 334.23 & 551.67 \\
\hline \multirow[t]{2}{*}{ Waste } & Mod. & 622.50 & 622.50 & 622.50 & 622.50 & 622.50 \\
\hline & Optim. & 622.50 & 622.50 & 622.50 & 622.50 & 622.50 \\
\hline \multirow[t]{2}{*}{ Total } & Mod. & $5,813.80$ & $6,171.85$ & $6,529.90$ & $6,887.94$ & $7,245.99$ \\
\hline & Optim. & $5,813.80$ & $6,584.25$ & $7,354.71$ & $8,895.62$ & $11,977.44$ \\
\hline \multirow[t]{2}{*}{ Increase } & Mod. & 0.00 & 358.05 & 716.10 & $1,074.14$ & $1,432.19$ \\
\hline & Optim. & 0.00 & 770.45 & $1,540.91$ & $3,081.82$ & $6,163.64$ \\
\hline
\end{tabular}

in 2030, while the share of wind power capacity will largely increase from $8.21 \%$ in 2010 to $34.61 \%$ in 2030. The solar PV power system also becomes more and more important for the contribution of renewable electricity in the future. Its share of installed capacity will expand from $0.3 \%$ in 2010 to $17.35 \%$ in 2030 .

The two scenarios demonstrate that wind power and solar PV power generation may provide a substantial contribution for capacity increase that will come from a wide array of new technology utilizing the full range of our renewable resources. Wind power is found to be potential along Taiwan's western coastline, Southern Peninsula, and Penghu group of islands and several small islands. The wind speed is greater than $4 \mathrm{~m} / \mathrm{s}$ at $10 \mathrm{~m}$ above ground in these areas. The total technical potential is estimated to be 4,600 MW for on shore wind power and 9,000 MW for offshore wind power (MOEA 2007). Considering the economic viability of siting wind turbines in various locations, the realizable potential, however, is somewhat malleable and reduced to 1,000 MW and 2,000 MW for onshore and offshore wind power, respectively (MOEA 2007, p. 58).

If the estimates of MOEA (2007) for realizable offshore wind power are accurate, our forecasts for the increase in wind power by 2030 indicated in the Optimistic Scenario seems to be too optimistic and cannot be achieved. The Optimistic Scenario projects that the cumulative wind power capacity will reach 2,311.58 MW by 2025 and $4,145.57 \mathrm{MW}$ by 2030 . This means that the newly increased capacity of wind power installation is 1,834 MW by 2025 beyond the realizable potential of on shore power $1,000 \mathrm{MW}$ or representing $91.7 \%$ of realizable potential of offshore wind power $(2,000 \mathrm{MW})$.
The total increase is $3,667.97 \mathrm{MW}$ by 2030 , beyond the sum of onshore and offshore realizable potential.

All the Taiwan's wind power is presently generated from onshore wind farms. As the western coastal is more dense in population, the development of onshore wind power projects is limited and hampered by public opposition due to adverse effects of noise concerns and aesthetics consideration. Offshore wind power has relatively advantage with higher wind speed that may generate more electricity. The development of wind power may focus on the offshore wind potentials. And thus, higher feed-in tariffs are provided to promote the investment of offshore wind power projects in Taiwan. Some IPPs argue that wind power capacity may be installed more, and the goal can be achieved easily if feed-in tariffs are increased by $100 \%$. Compared to the feed-in tariff of US $\varnothing 6.16$ (NT\$2.0) per KWH for wind power according to TPC's interim program, the feed-in tariff revised in 2011 was largely raised up to US $\notin 8.07$ (NT\$2.6138) per KWH for onshore wind power and US $\notin 18.54$ (NT\$ 5.5626) per KWH for offshore wind power.

EWEA (2011b) suggests that offshore wind power may contribute more for renewable power generation in the future. In 2010, offshore wind accounted for $3.5 \%$ of installed EU wind energy capacity (up from $2.7 \%$ in 2009). Wind power may be the most potential to develop and contribute significantly to achieve the goal of renewable power capacity due to the highly advance in offshore wind power technology.

Considering the competitive status of wind power with LNG fired and oil-fired power (De Carolis and Keith 2006; Morthorst 2009; Sovacool 2008), the development of wind power is viable and used to replace fossil-fired power. 
Taiwan may endeavor more to exploit wind power as a clean energy resource to achieve a zero-emission country. If Taiwan's wind power capacity can be expanded according to the Optimistic Scenario, 20-30\% of total power consumption in the future can be provided by the clean wind energy that emits less $\mathrm{CO} 2$. However, opposition to the installation of large infrastructure facilities has occurred and explained by the Not-In-My-Backyard (NIMBY) syndrome due to the adverse impacts ("spoiling of the landscape," noise, etc.) of large renewable energy projects. In order to bridge the energy supply gap, the micro-generation technology like solar PV systems is encouraged and may become a potential future energy supplies (Faiers and Neame 2006).

The projection on the solar PV may be the most uncertain among the renewable power generation technology, as the development of solar PV power systems is largely affected by the cost trends and the FIT policy. The growth of solar PV power system may deviate from the actual electricity demand and beyond the goal if the tariff is much higher than the cost. On the contrary, the growth will be blocked if the tariff is not attractive.

Based on the current technology, the capital cost for the installation of various renewable power systems is US\$ 6-10,000 per kwp for solar PV power, US\$ 3-4,000 per kwp for fuel cells, US\$ 1,500-3,000 per kwp for wind turbines, and US\$ 1,500-1,800 per kwp for biomass generators (EIA 2013). Between solar PV and wind power, Trapani et al. (2013) find that thin film PV is economically competitive compared to offshore wind power for latitudes ranging from $45^{\circ} \mathrm{N}$ to $45^{\circ} \mathrm{S}$. Compared to wind technology, the PV technology is newly emerging and thus changing quickly over time. A newer generation of technology may rise up efficiency and reduce costs. The past evolution of PV markets shows that the price reduction in PV products has become a trend. The global average price of PV modules declined by $23 \%$ from $\$ 4.75 / \mathrm{W}$ in 1998 to $\$ 3.65 / \mathrm{W}$ in 2008. During the period 2002-2007, module prices rose slightly due to the shortage of polysilicon material supply. After 2007, the price kept a downward trend by decreasing from $\$ 4.07 / \mathrm{W}$ in 2007 to $\$ 3.65 / \mathrm{W}$ in 2008 (NREL 2011). In general, "The price of PV modules has reduced by $22 \%$ each time the cumulative installed capacity has doubled" (EPIA 2011b, p. 30). The impact of competing technology may affect the future installation of renewable power systems and the corresponding renewable power market. The change in technology development and tariffs over time may enlarge the variation of newly installation in the consecutive years.

In general, the service life of solar PV modules can last for 25-30 years as the industry in general provides such a long time of warranty period (Fthenakis 2000; McDonald and Pearce 2010). As the spent modules contains high amount of glass, heavy metal and a variety of semiconductor materials that may yield adverse impacts on the environment but are valuable, the spent modules at the end of life should be collected and recycled based on proven methods to support the sustainable use of raw material. In practice, the recycling process has been developed successfully and used commercially for both thin film and silicon modules in developed countries. The recovered materials from the spent modules including glass breakage, defect laminate, electrical defects can be reused in either new PV modules or other new products. Thus, the recycling of the defected modules may benefit for both the environment and the PV producers as it can help reduce costs and environmental impacts. Some researchers have addressed the issues in association with the recycling of spent solar panels. For example, McDonald and Pearce (2010) compare the recycling process of five types of PV material-based solar cells and evaluate the amount of the semiconductor material and the recoverable semiconductor material by recycling from the module. Marwede and Reller (2012) estimate the amount of tellurium that can be recovered from PV scrap to substitute for primary tellurium by using a dynamic material flow model for the life cycle of CdTe-PV modules. Kreiger et al. (2013) conduct a life cycle analysis (LCA) on conventional solar PV systems. Their research result finds that a silane loss is reduced to $17 \%$ from $85 \%$ of conventional processing method by using a recycling process. However, Taiwan has not yet established the $\mathrm{PV}$ recycling systems due to low installed capacity of solar $\mathrm{PV}$. The recycling of spent solar panels is integrated with the spent electronic parts, printed circuit boards, and used computers through a variety of collection and processing channels.

\section{Conclusion}

This paper contributes to the review on the current status of renewable power generation in the leading countries and compares the FIT policies between the leading countries and Taiwan. As a follower to adopt FIT mechanisms to develop renewable energies, Taiwan has to face a lot of challenges that stands on the road. The goal of 6,500-10,000 MW new capacity installation within 20 years seems to be optimistic. The attainment of the goal is significantly affected by the intensity of the FIT policy to expedite renewable power expansion. Of course, the accuracy of our estimation may be affected by the technical and policy uncertainty. The technical uncertainty stems from the nature of technology development and diffusion. A large room still exists for soar $\mathrm{PV}$ and wind power technology to improve the conversion efficiency and reduce the power generation cost.

The policy uncertainty is owing to the rapid change of FIT schemes and scheme validity. According to the current 
regulation, the feed-in tariff will be reviewed every year and reduced if the new installation capacity reaches to the goal. Such a system may block the investment desire for the continual installation of renewable power systems. Thus, the main policy challenges may lie at (1) the design of an appropriate feed-in tariff scheme among various types of technology that can encourage the development of potential one, (2) the level of feed-in tariff that can sufficiently attract investment with an attractive rate of return, and (3) a policy certainty that can cover the risk of technical uncertainty.

Acknowledgments We are grateful to anonymous reviewers for their valuable comments and suggestions on an earlier version of this paper. The responsibility for any error remained in this paper should be born by the author. In addition, the author thanks National Science Committee (Taiwan) for its financial support under contract no.: NSC 98-2410-H-343-001-MY3.

\section{References}

Ackermann T, Andersson G, Svder L (2001) Overview of government and market driven programs for the promotion of renewable power generation. Renew Energy 22:197-204

Astrand K, Neij L (2006) An assessment of governmental wind power programmes in Sweden-using a systems approach. Energy Policy 34(3):277-296

BOE (Bureau of Energy) (2009) Taiwan's energy policy: supply and demand situation. Energy. Taipei: Bureau of Energy, Taiwan

BOE (Bureau of Energy) (2012) Energy statistics handbook 2011. Taipei: Bureau of Energy, Taiwan

Butler L, Neuhoff K (2008) Comparison of feed-in tariff, quota and auction mechanisms to support wind power development. Renew Energy 33:1854-1867

Chen CC (2010) Spatial inequality in municipal solid waste disposal across regions in developing countries. Int J Environ Sci Tech 7(3):447-456

Chen CC, Chen YT (2008) Income effect or policy result: a test of the Environmental Kuznets Curve. J Clean Prod 16:59-65

Couture T, Gagnon Y (2010) An analysis of feed-in tariff remuneration models: implications for renewable energy investment. Energy Policy 38:955-965

De Carolis JF, Keith DW (2006) The economics of large-scale wind power in a carbon constrained world. Energy Policy 34:395-410

Del Rio P, Gual MA (2007) An integrated assessment of the feed-in tariff system in Spain. Energy Policy 35:994-1012

Dincer F (2011) Overview of the photovoltaic technology status and perspective in Turkey. Renew Sustain Energy Rev 15:3768-3779

EIA (Energy Information Administration) (2011) International Energy Data. available at: http://www.eia.gov/emeu/international/energy. html

EIA (Energy Information Administration) (2013) Assumptions to the Annual Energy Outlook 2010. http://www.eia.gov/oiaf/aeo/ assumption/pdf/renewable.pdf

EPIA (European Photovoltaic Industry Association) (2011a) Global market outlook for photovoltaics until 2015

EPIA (European Photovoltaic Industry Association) (2011b) Solar generation 6: Solar photovoltaic electricity empowering the world 2011

EWEA (the European Wind Energy Association) (2011a) Annual Report 2010: Powering the energy debate
EWEA (the European Wind Energy Association) (2011b) Pure power, Wind energy goals for 2020 and 2030

Faiers A, Neame C (2006) Consumer attitudes towards domestic solar power systems. Energy Policy 34:1797-1806

Finon D, Perez Y (2007) The social efficiency of instruments of promotion of renewable energies: a transaction-cost perspective. Ecol Econ 62(1):77-92

Fouquet D, Johansson TB (2008) European renewable energy policy at crossroads: focus on electricity support mechanisms. Energy Policy 36(11):4079-4092

Foxon TJ, Pearson PJG (2007) Towards improved policy processes for promoting innovation in renewable electricity technologies in the UK. Energy Policy 35:1539-1550

Foxon T, Gross R, Chase A, Howes J, Arnall A, Anderson D (2005) UK innovation systems for new and renewable energy technologies: drivers, barriers and systems failures. Energy Pol 33:2123-2137

Fthenakis VM (2000) End-of-life management and recycling of PV modules. Energy Policy 28:1051-1058

IEA (International Energy Agency) (2011) International data statistics. http://www.iea.org/stats/renewdata.asp?

Jacobsson S, Lauber V (2006) The politics and policy of energy system transformation-explaining the German diffusion of renewable energy technology. Energy Policy 34(3):256-276

Klein A (2008) Feed-in tariff designs: options to support electricity from renewable energy sources. Lightning Source Inc., Tennessee

Kreiger MA, Shonnard DR, Pearce JM (2013) Life cycle analysis of silane recycling in amorphous silicon-based solar photovoltaic manufacturing. Resour Conserv Recycl 70:44-49

Langniss O, Diekmann J, Lehr U (2009) Advanced mechanisms for the promotion of renewable energy: models for the future evolution of the German renewable energy act. Energy Policy 37(4):1289-1297

Lipp J (2007) Lessons for effective renewable electricity policy from Denmark, Germany and the United Kingdom. Energy Policy 35(11):5481-5495

MacKenzie JJ (2003) Technology growth curves: a new approach to reducing global $\mathrm{CO}_{2}$ emissions. Energy Policy 31:1183-1187

Marwede M, Reller A (2012) Future recycling flows of tellurium from cadmium telluride photovoltaic waste. Resour Conserv Recycl 69:35-49

McDonald NC, Pearce JM (2010) Producer responsibility and recycling solar photovoltaic modules. Energy Policy 38:7041-7047

Mendonca M (2007) Feed-in tariffs: accelerating the deployment of renewable energy, ISBN 9781844074662. Earth Scan, London

Meyer NI (2003) European schemes for promoting renewables in liberalized markets. Energy Policy 31:665-676

Mitchell C, Connor P (2004) Renewable energy policy in the UK 1990-2003. Energy Policy 32:1935-1947

Mitchell C, Bauknecht E, Connor PM (2006) Effectiveness through risk reduction: a comparison of the renewable obligation in England and Wales and the feed-in system in Germany. Energy Policy 34(3):297-305

MOEA (2005) The 2005 White Paper for energy policy. Taipei: Minister of Economic Affairs, Taiwan

MOEA (2007) The 2007 White Paper for energy technology research and development. Taipei: Minister of Economic Affairs, Taiwan

Morthorst PE (2009) Awerbuch S. In: Krohn S (ed) The economics of wind energy. European Wind Energy Association, Belgium

NREL (2011) http://www.nrel.gov/analysis/market_re_data_solar.html

Rowlands I (2005) Envisaging feed-in tariffs for solar photovoltaic electricity: European lessons for Canada. Renew Sustain Energy Rev 9:51-68 
Rowlands I (2007) The development of renewable electricity policy in the province of Ontario: the influence of ideas and timing. Rev Policy Res 24(3): 185-207

Sarzynski A, Larrieu J, Shrimali G (2012) The impact of state financial incentives on market deployment of solar technology. Energy Policy 46:550-557

Sovacool BK (2008) The dirty energy Dilemma: what's blocking clean power in the United States. Praeger Publishers, Santa Barbara

Terrados J, Almonacid G, Hontoria L (2007) Regional energy planning through SWOT analysis and strategic planning tools: impact on renewables development. Renew Sustain Energy Rev 11:1275-1287

Trapani K, Millar DL, Smith HCM (2013) Novel offshore application of photovoltaics in comparison to conventional marine renewable energy technologies. Renew Energy 50:879-888

Wiser R, Bolinger M (2010) The 2009 wind technologies market report. Published by NREL (National Renewable Energy Laboratory), available at http://www.nrel.gov/docs/fy10osti/48666.pdf 